\title{
ОГЛЯД РИНКУ ТЕПЛОІЗОЛЯЦИЙНИХ МАТЕРІАЛІВ НА ОСНОВІ РОСЛИННОЇ СИРОВИНИ
}

\author{
И.А. ДУДЛА, А.Б. МИКУЛИЧ, Г.И.ГОЛОДЮК \\ Луиякий национальный технический университет
}

\section{ОБЗОР РЫНКА ТЕПЛОИЗОЛЯЦИОННЫХ МАТЕРИАЛОВ НА ОСНОВЕ РАСТИТЕЛЬНОГО СЫРЬЯ}

\author{
I.DUDLA, A. MIKULICH, G.GOLODUK \\ Lutsk national technical university
}

\section{REVIEW OF THE MARKET OF HEAT INSULATION MATERIALS ON THE BASIS OF PLANT RAW MATERIAL}

\section{https://doi.org/10.36910/6775-2310-5283-2018-11-10}

Мета. Розглянути сучасні теплоізоляџійні матеріали на основі рослинної сировини, які є на українському ринку.

Методика. Методологічну базу роботи склали фундаментальні $і$ прикладні дослідження $і$ аналіз теплоізолячійних матеріалів, які представлені на ринку України, згідно діючих стандартів. В процесі роботи використовувались дані Державного комітету статистики, матеріали статей та Інтернет - конференцій з даної теми дослідження трунтується на методах аналізу, синтезу та узагальнення

Результати. Для забезпечення енергозбереження в будівлях і спорудах необхідно застосовувати вітчизняний теплоізоляційний матеріал на основі рослинної сировини.

Наукова новизна. Систематизовано основні теплоізоляційні матеріали, які найтирие використовуються в будівництві, проведено дослідження їх властивостей $i$ виробниитва найбільш ефективного матеріалу на основі рослинної сировини.

Практичне значення. На особливу увагу заслуговує теплоізоляційний плити «Соломат», які виготовлені з додаванням сировини рослинного походження, характеризуються необхідними властивостями $i$, можуть бути прийняті для дослідження які направлені на його удосконалення. Результати дослідження можуть бути використані у виробництві теплоізолячійних плит, які використовуються для теплоізоляиії будівель і споруд.

Ключові слова: теплоізоляційні матеріали, костриця, будівельні матеріали, очерет, тростина, луска соняшника, солома зернових культур.

Поставка проблеми у загальному вигляді та їі зв'язок із важливими науковими чи практичними завданнями. У всьому світі приділяють велику увагу питанню теплоізоляції будинків та споруд, як найбільш ефективному 
напряму скорочення тепловитрат. В Україні питання теплозбереження в останні роки набуло великого значення. Однак за багатьма показниками ми суттєво відстаємо від розвинутих країн. На одиницю житлової площі в Україні витрачається в 2-3 рази більше енергії, ніж у країнах Свропи, де виробництво теплоізоляційних матеріалів на душу населення в 5-6 разів більше, 70 \% спожитих на Україні теплоізоляційних матеріалів є імпортом.

Сучасна будівля - складний комплекс різних інженерних систем, конструкцій і матеріалів, до якого пред’являється досить жорсткі вимоги, не лише такі традиційні, як стійкість до зовнішніх дій, естетичність і довговічність, але й нові, що відповідають сучасним уявленням про цілі та завдання будівництва [1]. Серед них перш за все виділяють: енергоефективність, комфортність, економією паливних ресурсів і зниженням шкідливих викидів в атмосферу [1]. Перспективним способом захисту будівельних конструкцій від втрат тепла це використання теплоізоляційними матеріалами, які повинні мінімізувати втрати тепла. Захист будівельних конструкцій здійснюється різними теплоізоляційними матеріалам, які завдяки високим показникам не тільки знижують тепловтрату, але й забезпечують економію паливо-енергетичних ресурсів. Для забезпечення енергозбереження в будівлях необхідно застосовувати вітчизняний теплоізоляційний матеріал, який виготовлено з екологічно-чистого наповнювача. Проблема використання відходів рослинного походження як сировини для виробництва теплоізоляційних матеріалів набуло в останні час актуальності [2].

Вивченню властивостей $\mathrm{i}$ технології матеріалів та проблеми використання сучасних теплоізоляційних матеріалів із рослинної сировини присвячені роботи вітчизняних і закордонних дослідників М. Совицького, К. Собінова, О. Зінкевич, О. Ожищенка, М. Бабенка. В Україні існують офіційно затверджені норми конструкцій зовнішніх стін із фасадною теплоізоляцією [3]. Стандарт встановлює класифікацію системи теплоізоляції, загальні технічні вимоги, основні вимоги до проектування, правила влаштування та експлуатації, а також метод визначення стійкості конструкцій теплоізоляції до кліматичних впливів.

Цілі статті. Теоретичне вивчення і аналіз теплоізоляційних матеріалів, ринку України органічного походження.

Об'єкт дослідження. Теплоізоляційні матеріали на основі рослинної сировини, які є на ринку України і оцінити ефективність їх використання.

Методи дослідження. Метод експертних оцінок та методи, які передбачені діючими стандартами. 
Виклад основного матеріалу дослідження з повним обгрунтуванням отриманих наукових результатів. Основним напрямом економічного i соціального розвитку в умовах енергетичної кризи у всьому світі і в Україні $\epsilon$ розвиток виробництва ефективних будівельних матеріалів і економія паливноенергетичних ресурсів, включаючи мінімізацію теплових втрат утеплених будівель. Рано чи пізно проблема зниження тепловтрат постає практично перед кожним власником нерухомості. Правильний обгрунтований вибір теплоізоляції $\epsilon$ найважливішою умовою для створення комфортного мікроклімату приміщення.

За останні роки вченими Ю. Бобровим, В. Граневим, В. Курдюмовою, Н. Гончаровим, А. Люсевим велика увага приділялась широкому використанню відходів промисловості і сільського господарства в виробництві теплоізоляційних матеріалів.

Використання відходів рослинного походження як сировини для виробництва теплоізоляційних матеріалів набуло в останній час особливої актуальності. По - перше, це дозволяє вирішити проблему утилізації відходів деревообробних і сільськогосподарських підприємств, по - друге, отримати дешеву місцеву сировину для виготовлення нових матеріалів. В теперішній час такі дослідження інтенсивно проводять у багатьох країнах, що обумовлено ростом дефіциту деревини для будівельних виробів.

За аналізом досліджень М. Баумова, Н. Новак, В. Курдюмова, А. Ставчинського, Т. Румако встановлено, що найбільш прийнятною сировиною для виробництва теплоізоляційних матеріалів $€$ лігнецелюлозні сільськогосподарські відходи, які отримують після збирання урожаю: очерет, тростина, луска соняшника, солома зернових культур. Виготовляють вироби на основі різноманітних органічних волокон рослинного походження - м'які деревоволокнисті плити, арболіт, фіброліт, льонокостричні, торф'яні, 3 очеретів плити, корліт, риліт, костроліт, ортекс, страміт і інші.

Одним із перших об'єктів дослідження по застосуванню рослинної сировини для виробництва будівельних матеріалів стала костриця льону відходи від рослин льону i коноплі, після первинної обробки, які використовуються в прядильній промисловості.

Склад костриці: лігнін (21..29\%), целюлоза (45...58\%), пентоза (23...26\%). Костра складається із частинок розміром $10 \ldots 20$ мм, довжиною і товщиною $0,1 \ldots 1,5$ мм (рис. 1). Використовується костриця в будівництві для виготовлення теплоізоляційних матеріалів і як наповнювач для матеріалів 3 поліпшеними теплотехнічними показниками. 




Рис. 1. Костриця льону

Перша установка для виробництва плит із льняних частинок була запущена в Бельгії в 1947 році на заводі фірми «Лінекс».

Отже, основні переваги використання костриці при будівництві: костриця - екологічно чистий матеріал; матеріали із застосуванням костриці мають відносно невисоку вартість; костриця $є$ природним антисептиком; матеріали із застосуванням костриці характеризуються хорошими звукоізоляційними властивостями; відносно висока довговічність; костриця не гниє. При тривалій експлуатації не втрачає своїх первинних властивостей; біологічно стійка. Костриця не знищується гризунами і комахами; високий показник паропроникності, і пористості, що дозволяє стіні «дихати». Також, висока паропроникність виключає і скупчення конденсату в стінах, оскільки утворення конденсату в стінних матеріалах приводить до різкого зниження теплотехнічних показників і руйнування матеріалу при замерзанні.

Ефективними теплоізоляційними матеріалами $є$ очерет, але він не біостійкий, що дозволяє використовувати його тільки в другорядних будівельних конструкціях. Поверхневий шар стебла очерету має підвищений вміст кремнію, що затрудняє його згорання, він не горить, а тліє. Для підвищення водостійкості плити обробляються ззовні емалями і нітролаками.

Для виробництва волокнистих плит вивчена можливість [3] використання соломи, лушпиння, костриці, макулатури. В якості наповнювача при розробці теплоізоляційних матеріалів використовують подрібнену солому зернових культур (пшениці) - відходи сільськогосподарського виробництва. Застосування соломи при виготовленні теплоізоляційних плит обгрунтоване тим, що вона є екологічно - чистою сировиною. Оскільки більше $50 \%$ земель використовуються під вирощування зернових культур. Територія України 
займає 603628 км², в користуванні сільськогосподарських підприємств знаходиться 42 млн.га.

При збиранні основної частини врожаю - зерна, господарства збирають i іншу - не зернову частину це солому. Солома у ваговому вираженні більше ваги зерна в 1,5-2 раза, а за об'ємом - в 5-7 раз. При середній урожайності: жита - 25 ц/га, озимої пшениці 24 ц/га, ярої пшениці - 28 ц/га валовий збір соломи складає близько 2000 тис.т щорічно. Збирання не зернової частини врожаю є найбільш трудомісткою і відповідальною операцією в технології збирання зернових. Від швидкості і якості проведення цієї операції залежить успіх майбутнього врожаю, так як не своєчасне збирання соломи може привести до затримки поля до посіву. Все це приводить до додаткових витрат на збирання, перевезення і складування соломи, які повністю не окупні i відбиваються на вартості зерна. Не оправдовує себе i спосіб, який використовують деякі господарства, при якому солома при збиранні подрібнюється і розкидається по полі 3 подальшим його заорюванням для підживлення землі. В цьому випадку відбувається забруднення полів бур'янами і очікуваного результату не досягається. Тому, в основному, частина соломи заготовлюється для використання його як добавка до кормів, а також в якості матеріалу для настилу на тваринницьких фермах. Вся інша солома спалюється. Таким чином економічно і технічно обгрунтовано використання соломи, як допоміжного матеріалу для виготовлення теплоізоляційних матеріалів.

Для підвищення технологічних i експлуатаційних властивостей теплоізоляційних матеріалів використовують змішаний наповнювач на основі соломи. В якості другого компоненту органічного наповнювача використовують волокнисті відходи хутряного виробництва.

Таким чином, теплоізоляційний матеріал пористо-волокнистої структури, до яких відносяться розглянуті органічні теплоізоляційні матеріали на основі рослинної сировини не можуть відноситись в даний час до перспективних ізоляційних матеріалів, хоча більшість 3 них i характеризуються високими теплотехнічними показниками. Поки що вони використовуються лише в другорядних будівельних конструкціях. Для можливості масового використання і збільшення об'єму їх виробництва необхідно шукати нові шляхи зниження вологопоглинання, підвищення біостійкості і стійкості до горіння нових матеріалів на основі сільськогосподарських відходів, а саме, подрібненої соломи. 
Iз розглянутих в даному огляді даних випливає, що на основі соломи можуть бути виготовлені різні варіанти теплоізоляційного матеріалу. Структура їх подана на рис.2.

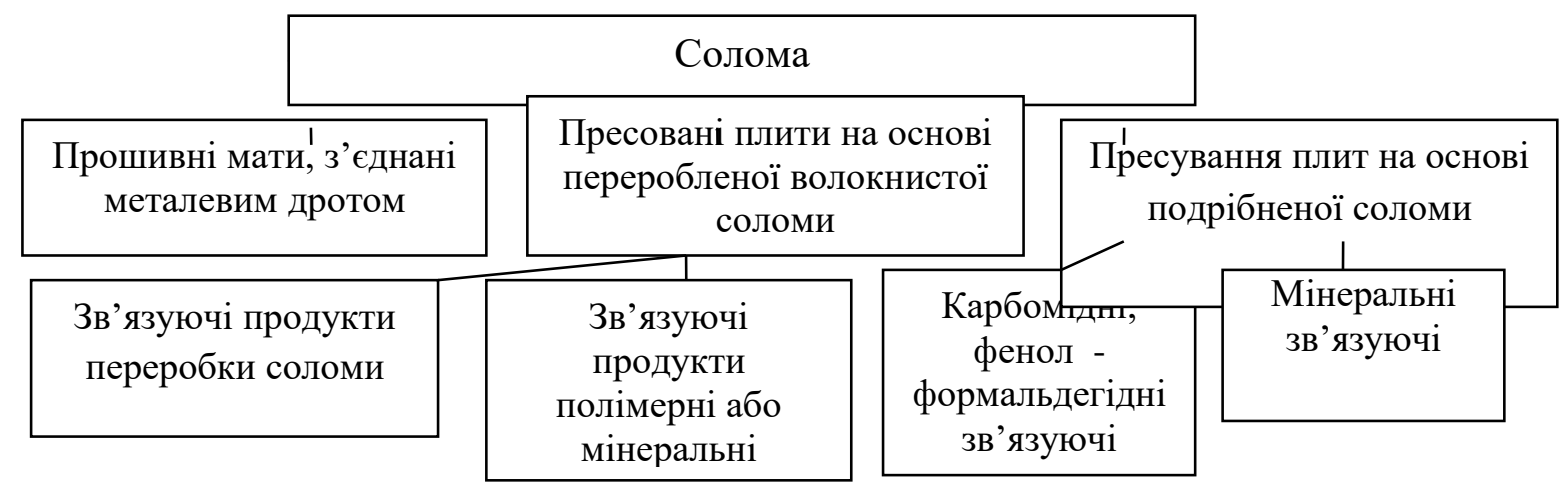

\section{Рис. 2. Використання соломи в виробництві теплоізоляційних матеріалів}

Пресовані плити на основі подрібненої соломи за своїми технологічними, експлуатаційними i техніко-економічними параметрами можна вважати найбільш перспективними в порівнянні з прошивними матами i плитами на основі переробленої термічним або термохімічним шляхом волокнистої соломи.

При обробці насіння на олійнопресовому заводі залишається дуже багато лушпиння. Її обсяг часом перевищує 14 \% від загальної кількості насіння. Утилізація такого обсягу достатньо проблематична і недешева. На щастя, сьогодні можна знайти багато варіантів утилізації лушпиння з користю в господарстві. Широко використовується в будівництві для виготовлення теплоізоляційних плит.

Розроблена технологія має специфічні особливості із-за наявності воскового покриття на поверхні частинок лушпиння, яке призупиняє всмоктування зв'язуючого в пори. В якості зв'язуючого пропонується мочевинно-формальдегідні смоли в кількості 9-12\% від маси сухого лушпиння.

Висновки та перспективи поданих досліджень. Плити 3 теплоізоляційного матеріалу органічного походження не мають правильної волокнистої структури, основна частина волокон розміщується паралельно плоскої сторони плити, але деяка частина волокон розміщується нормально або під кутом до цієї площини. Причому у деяких матеріалів типу торфоплити, фіброліту, довжина волокон зовсім не рівномірна i тому матеріали такого типу можуть бути віднесені до змішаного типу. 
Встановлено, що найбільшими величинами теплопровідності характеризуються матеріали фіброліт, які мають порівняно грубу структуру, а найменшими - матеріалами із розщепленого деревинного волокна (ДВП), які мають дисперсну структуру.

При розробці нових типів теплоізоляційних матеріалів необхідно враховувати умови експлуатації матеріалів, тобто він не повинен змінювати свою форму при температурі $100{ }^{0} \mathrm{C}$, розкладатися, руйнуватися. Матеріал повинен бути стійким, якщо умови експлуатації пов’язані зі зміною температури та вологи.

\section{Література}

1. ДБН В.2.6-31: 2006. Конструкції будинків і споруд. Теплова ізоляції будівель. - К: Мінбудархітектури України, 2006. - 71 с.

2. ДСТУ В.2.6-36: 2008 Конструкції зовнішніх стін із фасадною теплоізоляцією та опорядженням штукатурками. К.: Мінбудархітектури України, 2009. - 43 с.

3. Козлов Ю.Д. Волокнистые плиты из отходов c/х и макулатуры // Строит. Материалы и конструкции. - 1994. - 32 с.

4. Живетин В.В. Лен и его комплексное использование. - М.: Информ - Знание, 2002. $-400 \mathrm{c}$.

5. Смирнов О.Э. Строительные теплоизоляционные материалы на основе отходов льнопереработки /О.Э. Смирнова// межд.сб.науч.тр. «Материалы и изделия для ремонта и строительства. Новосибирск. - 2006. - С25-26 (432).

6. Чижек Я. Свойства и обработка древесностружечных и древесноволокнистых плит. Пер. с чешск. /отв. Ред. В.Д.Бекетов. - М.: Лесная промышленность, 1989. - 392 с.

7. Щербак А.С. Исследование свойств современных теплоизоляционных матероиалов / А. С. Щербак // Наука та прогрес транспорту. - 2013. -№ 2(44). - С. 136-143.

8. Петров А. Н. Теплоизоляционные материалы на основе соломы и неорганических связующих // Режим доступу: http://tekhnosfera.com/teploizolyatsionnye-materialy-na-osnovesolomy-i-neorganicheskih-svyazuyuschih\#ixzz53xfcC0zg.

9. Смирнова О.Е., Теплоизоляционные материалы на основе костры льна: дис. кандидата техн. наук: 05.23.05. - Новосибирск, 2007. - 137 с.

Цель. Рассмотреть представленные на украинском рынке современные теплоизоляционные материалы на основе растительного сырья.

Методика. Методологическую базу работь составили фундаментальные и прикладные исследования теплоизоляционных материалов, представленных на рынке Украины. В процессе работь использовались данные Государственного комитета статистики, материаль статей и Интернет-конференций по данной теме исследования. Для обработки данных использовались методах анализа, синтеза и обобщения информации.

Результаты. Для обеспечения энергосбережения в зданиях и сооружениях необходимо применять отечественный теплоизоляционный материал на основе растительного сырья. 
Научная новизна. Систематизированы основные теплоизоляционные материаль, которые широко используются в строительстве, проведено исследование их свойств.

Практическое значение. Особого внимания заслуживает теплоизоляционный плиты - «Соломат», изготовленные с добавлением сырья растительного происхождения, характеризуются необходимыми свойствами и могут быть приняты для исследования направленные на его совершенствование. Результаты исследования могут быть использованы в производстве теплоизоляционных плит, которые используются для теплоизолячии зданий и сооружений.

Ключевые слова: теплоизолячионные материаль, овсяница, строительные материаль, камыш, тростник, чешуя подсолнечника, солома зерновых культур.

The purpose of the article is to review modern plant-based heat-insulting materials that are available on Ukrainian market.

Methodology. The article is based on fundamental and practical research and on the analysis of heat-insulting materials, which are available on Ukrainian market, according to current standards. The data of the State Statistics Committee, articles and materials of Internetconferences were also used in the work process.

Results. It is necessary to use national plant-based heat-insulting material in order to provide energy saving in the buildings.

Originality. The main heat-insulting materials, which are widely used in construction, were systemized, the research of their properties was carried out and the most effective methods of manufacturing heat-insulting materials were found.

Practical value. The greatest attention is paid to the heat-insulting slabs "Solomat" which are plant-based and have all the necessary properties to be accepted for the research that shows the ways of their improvement. The results of this research can be used in heat-insulting slabs manufacturing.

Key words: heat-insulting materials, building materials, cane, reed, sunflower scale, straw of grain crops.

Рекомендовано до публікаиії докт.техн.наук. професором Луиького НТУ Байдаковою Л.І. Дата надходження в редакиію 31.01.2018 